\title{
Insulin-Like Growth Factor-Binding Protein 5
}

National Cancer Institute

\section{Source}

National Cancer Institute. Insulin-Like Growth Factor-Binding Protein 5. NCI Thesaurus.

Code C17508.

Insulin-like growth factor-binding protein 5 (272 aa, $31 \mathrm{kDa}$ ) is encoded by the human IGFBP5 gene. This protein is involved in promoting increased half-life of and modulating receptor binding by insulin-like growth factors. 